International Journal of English Literature and Social Sciences
Vol-6, Issue-3; May-Jun, 2021
Journal Home Page Available: https://ijels.com/
Journal DOI: $10.22161 /$ ijels

Peer-Reviewed Journal

\title{
Potheri Kunhambu; The social reformer from North
} Malabar

\section{Bijina M.}

Assistant Professor, Department of History, C.A.S College Madayi, Kannur District, India

Received: 03 Feb 2021; Received in revised form: 29 Mar 2021; Accepted: 30 Apr 2021; Available online: 17 May 2021

(C2021 The Author(s). Published by Infogain Publication. This is an open access article under the CC BY license

(https://creativecommons.org/licenses/by/4.0/).

\begin{abstract}
Potheri Kunhambu was an eminent social reformer from North Malabar. He belongs to Thiyya community. He mainly focused for the upliftment of lower communities especially pulayas of North Malabar. His activities were ridiculed by the caste hindus and they called him as "Pulayan Kunhambu". The objective of this paper is to examine the role of Potheri Kunhambu and his Novel "Saraswathivijayam" in the upliftment of lower communities of Malabar.
\end{abstract}

Keywords-Colonial Intelligentsia, Caste, Untouchability, Downtrodden people.

\section{INTRODUCTION}

In the traditional period the social set up of North Malabar was very pathathetic everything was controlled under the institution of caste. Caste was the prime institution and every decision and position was controlled on the basis of caste. In this circumstances the lower caste people had been faced several problems and sufferings. Potheri Kuhambu was from Thiyya community of North Malabar, he had been faced several caste related issues and already know the conditions of Thiyyas and other lower caste people.

Potheri Kuhambu was a typical colonial intelligentsia. He was a well known and efficient advocate from chirakkal Taluk. He was a reputed literary figure at that time . Even now a days people in academic and literary circles discuss his contribution as a writer who dealt with the issues of the downtrodden.

Potheri Kunhambu was born at Pallikunnu near Kannur on 6th June 1857. Kunhambu's elementary education was from his father Onakkn's Ezhuthupalli. His first teacher was Kunhumbutti gurukkal. After his elementary education he went to Kannur for studying English. Even he was studying in school he had several peculiar qualities like punctuality and honesty. Punctuality and honesty was the hallmarks of kuhambu's sucess. After his matriculation examination there was financial problem in the family. Therefore he had to discontinue and join the service as postmaster. Kunhambu tried to raise fund for students for the education of the poor student without getting the help of their parents. It seems that he gave special attention to provide financial support to poor students for education because he himself suffered the same problem during his studies. Potheri Kunhambu was a broad minded person. Several poor people lived under the dependence of kunhambu. In the preface of the Novel itself, Potheri Kunhambu, tries to convey an important message that "Education is the greatest wealth" to attain progress ${ }^{1}$.He gave equal importance to the education of his own children and those of his relatives and other people. Few years later he became a gumastha under an advocate at Thaliparamba. After that he decided to appear for advocate examination, and qualified the same, hence he became an advocate at Munsif court at Thaliparamba. When the chavassery musif court was shifted to kannur Kunhambu became the Advocate at this court.

Besides being a community reformer and writer, Kunhambu was a good and efficient advocate. He dedicated his whole life for engaging the social reform activities and gave due consideration for the upliftment of pulayas and untouchable castes. He used his pen as a

\footnotetext{
1 Potheri Kunhambu, Saraswathivijayam,(Mal.novel), Reprint, Chinta Publishers, Thiruvanthapuram, 2013
} 
weapon for fight against caste system and untouchability and other social issues existed during that period. He spend his time engaged in the journalistic activities and contributed articles in Kerala Patrika,Kerala Sanchari and Bashaposhini.All his articles he raised one and only issue was the sufferings of the lower communities and fght against Brahmin domination.On the basis of this social issue he wrote a novel saraswathivijayam in the year 1892." The pulayas of Malabar are in a sorry state: this was the provocation for writing the novel ${ }^{2}$ ". He used this novel as a weapon for social reform. At that time education was the monopoly of the upper castes and the lower caste people were not permitted to receive education.At the same time Sanskrit education was the monopoly of the Brahmins. Education is the greatest wealth was the main theme of the novel.Education is the greatest factor of one whoearned the higher position in the society.Through education he earned higher position in the so ciety.This novel he clearly portrayed the conditions of society during that period.It is noteworthy that Kunhambu was a role model for other advocates at that time. $\mathrm{He}$ treated his client's case as his own case and dedicated his whole time and energy for the success of the case in the court. He didn't spend any money for luxurious life. Potheri Kunhambu earned fame for his own hard work punctuality and honesty.

Potheri Kunhambu's first wife whose name was Chiruthei. He had three children in this relation. First son was kunhikannan, he was the manager of Malabar bank and also a strong and ardent follower of Sree Narayana Guru. His daughter Dr.Paruamma obtained her higher education in medicine from USA. She was the first lady Gynecologist in Malabar. Her husband was a European, Dr.Millet $^{3}$. Next daughter was Janakki, she was also an educated lady. At his first wife was died due to an attack of lightening, he married her younger sister. In this relation he had three children, all were well placed. After the death of second wife Kunhambu married third time to take care of his children. From this marriage he had three sons, his elder son was Potheri Madhavan who became a member of Madras Legislative Asembly ${ }^{4}$. Second son was Uthaman , MSC/MS, Agricultural Scientist. Younger son was Krishnan, who became a school Teacher. The important works of Potheri Kunhambu are Saraswathivijayam, Thiyyar, Ramakrishna Sambadham ,Ramayana Sara Sadhana, Mythri, Bhagavad

\footnotetext{
${ }^{2}$ Dilip M. Menon, Caste and Colonial Modernity Reading Saraswathivijayam, Studies in History, New Delhi, 1997,p- 299

${ }^{3}$ Gurudevan Weekly, Volume 44, Lakkam7, March,2005

${ }^{4}$ Dilip M. Menon, Caste and Colonial Modernity Reading Saraswathivijayam, op.cit,p- 299
}

Geethopadesham $\mathrm{etc}^{5}$.He read many books related to different topic and made critical assessment of them besides he wrote several scholarly essays and published them in various newspapers to make the people aware of various social issues exist at that time. His Monograph "Thiyyar" clearly mentioned his sympathy towards his own community. In addition tohis duty as an advocate, he engaged in community service and other welfare programmes. The introduction of the book itself gives a detailed plan of his prorammes for the upliftment of Thiyya community ${ }^{6}$. Here the book "Thiyyar" points out that only five percentage of Thiyya community are educated and economically well paced. The rest of the Thiyya population remained in a condition of economic and educationally backward ${ }^{7}$. Kunhambu argued that western system of education is the only tool for the development of the community. The novel saraswathivijayam noted the theme was that English education greatly influenced the lowercaste and also helpful from the caste ridden society and they escaped from the particular caste bondge society ${ }^{8}$. He exclusively supported the colonial modernity ${ }^{9}$ and he argued that the only way to attain freedom from traditional caste bondage was to accept modernity and colonial perspective and supported the colonial view point because was that they never considered caste and creed they provided education for all. Colonialism freed from the people of traditional spiritual domain of Hinduism and caste system. He fight against the unnecessary customs existed in the traditional society of north Malabar ${ }^{10}$.

The novel saraswathivijayam is a didactic novel ${ }^{11}$ and its theme was not artificially created its was real life scenario of the nineteenth century North Malabar. He used this novel as a wepon for social reform ${ }^{12}$.

\section{CONCLUSION}

He was a typical colonial intelligentsia and social reformer. He dedicated his whole life for helping downtrodden people. He was the first person who described Pulayas as"Panchamas"13. Potheri Kunhambu started social reform movement even before the reform

\footnotetext{
5 Yoganatham ,SNDP Yogam,1977

${ }^{6}$ Ulloor.S.Parameswaran, Keralasahityacharitram, Vth Volume,Kerala Univerity, 1990,p. 307

7 Gurudevan Weekly, Volume 44, Lakkam7, March,2009

8 Dilip M menon, Caste and colonial modernity: Reading Saraswativijayam, studies in history,1997, p-292

${ }^{9}$ Ibid

${ }^{10}$ Gynodayayogam Samaranika, Thalassery,.2005, also see the same article details quoted from the famous work 'Thiyyar 'published by Potheri Kunhambu.

${ }^{11}$ Ibid, p-298

$12 \mathrm{lbid}, \mathrm{p}-298$

13 Ulloor.S.Parameswaran, Keralasahityacharitram,p.307
} 
activities of Ayyankali, and Sahodaran Ayyappan in Kerala. Potheri Kunhambu was known for his critics as "Pulayan kunhambu". We can see that Potheri Kunhambu was given the nickname "Pulayan Kunhambu" by the orthodox section even before Sahodaran Aiyappan received this ridiculed title ${ }^{14}$. He was the advocate of rationalist movement in kerala. His novel SaraswathiVijayam clearly depicted the problems of nineteenth century North Malabar. The author made crystal-clear depiction of social issues in this work ${ }^{15}$. It can be argued that it is the first novel written in the perspectives of the marginalized or the Dalits. Although the Novel Indulekha and SaraswathiVijayam were written in the same period, the later didn't get the popularity as Indulekha because in the SaraswathiVijayam was a strong critique of uppercaste domination and its ideology ${ }^{16}$. This novel created a revolution against social inequality and caste system. Also the novel we can considered as the first proletarian novel in Malayalam ${ }^{17}$. The novel SaraswathiVijayam is not a story for one family or one community it is a real social history of North Malabar in the nineteenth century.

\section{REFERENCES}

[1] Potheri Kunhambu, Saraswathivijayam, (Mal.novel), Reprint, Chinta Publishers, Thiruvanthapuram, 2013

[2] Dilip M. Menon, Caste and Colonial Modernity Reading Saraswathivijayam, Studies in History, New Delhi, 1997,p299

[3] Gurudevan Weekly, Volume 44, Lakkam7, March,2005

[4] Yoganatham, SNDP Yogam, 1977

[5] Ulloor.S.Parameswaran, Keralasahityacharitram, Vth Volume,Kerala Univerity, 1990

[6] Gurudevan Weekly, Volume 44, Lakkam7, March,2009

[7] Dilip M menon, Caste and colonial modernity: Reading Saraswativijayam, studies in history, 1997

[8] Gynodayayogam Samaranika, Thalassery,.2005,also see the same article details quoted from the famous work 'Thiyyar 'published by Potheri Kunhambu.

[9] Ulloor.S.Parameswaran, Keralasahityacharitram,p.307

[10] K.K Koch , Keralammaranna samoohya parishkarana prasthanam, in Sameeksha weekly, 1999

[11] George Irumbayam (edt), Nalu Novelukal(Mal), Trissur

[12] Mathurmbi weekly supplement, 2015 December 13

[13] Bhagyasheelan Chalad, Kannurinte Kalvilakkukal, Kairal Books, 2009

\footnotetext{
14 K.K Koch, Keralammaranna

samoohyaparishkaranaprasthanam , in Sameeksha weekly, 1999

${ }^{15}$ George Irumbayam (ed), Nalu Novelukal(Mal), Trissur, pp.11-

12

${ }^{16}$ Mathurmbi weekly supplement, 2015 December 13

17 Bhagyasheelan Chalad, Kannurinte Kalvilakkukal, Kairali

books,2009,p.36
}

ISSN: 2456-7620 